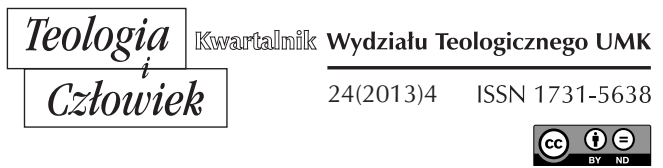

JULIAN BARRIO BARRIO*

\title{
TRANSCENDENTNY SENS SZLAKU ŚW. JAKUBA - CAMINO DE SANTIAGO
}

DOI: http://dx.doi.org/10.12775/TiCz.2013.052

Następnie zwróciło sie ku nam pewne światło Z owej sfery, z której wyszły pierwociny Które ze swoich zastępców zostawił Chrystus; A moja Pani, pełna radości

Mi powiedziała: Spójrz, spójrz, tam jest mąż

$\mathrm{Z}$ powodu którego, tam na dole, odwiedza się Galicję

Uśmiechając się wówczas rzekła Beatrycze:

Jaśniejące życie, dzięki któremu splendor

Naszej bazyliki został opisany

Spraw, aby usłyszano nadzieję na tej wysokości ${ }^{1}$.

(Dante Alighieri)

Będąc pielgrzymami na tym skrzyżowaniu cywilizacji i historii, jesteśmy wezwani do dokonania odczytania w perspektywie wiary obecnej rzeczywistości, korzystając ze światła lampy wiary, podarowanej nam przez Chrystusa: Światłość świata, Drogę (Camino), Prawdę i Życie.

* Ks. abp Julian Barrio Barrio, arcybiskup Santiago de Compostela w Hiszpanii.

${ }^{1}$ Dante Alighieri, Cántico tercero de la Divina Comedia. El Paraíso, Canto XXV. 
W ten sposób szukamy z pragnieniem, aby spotkać, i spotykamy z pragnieniem, aby dalej szukać, jak pisał św. Augustyn. W tym znaczeniu powinniśmy odkrywać nowe horyzonty, pamiętając o tym, skąd zaczyna się nasze pielgrzymowanie i mając na względzie metę, ku której zmierza. Doliny, góry, płaskowyże, czasami łatwe drogi do przebycia, innym razem trudniejsze, dzień i noc, to paradygmaty naszego pielgrzymowania religijnego, duchowego, społecznego i kulturowego. Również dziś, gdy pielgrzymujemy przez pustynię naszego życia potrzebujemy Mojżeszów, którzy dokonają cudów dotknięcia skały prawdy, dobra i piękna, aby otworzyć źródła, z których wytryśnie woda, zawsze wartka, duchowości katolickiej.

Mądrość nie pozwala nam być smutnymi pesymistami ani naiwnymi entuzjastami. Człowiek mądry pozostaje w harmonii ze wszystkim, co istnieje, nie traktuje [wszystkiego] jako konfrontacji i wiem, że zanim uda się coś poprawić w świecie, trzeba wiele poprawić wewnątrz samego siebie. Potrzebna jest analiza spokojna i głęboka, aby nie zaciemniły się blaski, które oświetlają życie ani nie przeszły niezauważone cienie. Życie polega na nauce i świadomości, że społeczeństwo nie może wymyśleć się od nowa w jakimkolwiek momencie, wyrzucając poza cały bagaż kulturalny i moralny, który został mu podarowany przez poprzednie pokolenia, jakby nic nie było w nim godnego przekazania; jakby każda zmiana równała się postępowi; jakby mógł mieć miejsce postęp, gdy się utraciło perspektywę celu, ku któremu winny zmierzać nasze kroki. Aby zrozumieć transcendentny sens Camino powinniśmy wyostrzyć swą wrażliwość na to, co niewidzialne, obserwując to, co widzialne, poruszając się na scenie tego antropologicznego i kulturowego kryzysu.

Joseph Bedier mówi, że „na początku była droga”, droga, którą wytyczyły pewne pokolenia, pokonując ją, a inne odkryły ją jako zastaną; jest to droga, która w każdym razie łączy wsie i miasta, i zawsze kieruje wędrowca ku mecie, którą chce osiągnąć. Ale nie ma drogi bez mety ani mety bez spotkania, a Miasto Apostoła pomaga w spotkaniu z tradycją apostolską, która stoi u podstaw naszej wiary. Szlak św. Jakuba ofiaruje pielgrzymowi nową przestrzeń, z jej wymaganiami, wiedzą i doświadczeniem, również nowymi. Sanchez Albornoz napisał: „Camino na ziemi i w niebie. Droga materialna prowadząca przez różne oblicza ziemi... i droga bardziej subtelna, ale trwalsza, w rejonach panowania ducha; droga niedotykalna i niewidzialna, przez którą nie idą ciała, ale którą przeszły tłumy; idee, formy artystyczne czy literackie, instytucje, uczucia, sprawności". Szlak naznaczał się pytaniami, poszukiwaniem i nadzie- 
ją, aby dotrzeć do duchowego serca tradycji apostolskiej. Wykraczając poza ujęcie estetyczne czy artystyczne, bicie "Camino" daje się odczuć na transcendentnym pulsie życia duchowego, które jest wyczuwalne $\mathrm{w}$ pielgrzymim wędrowaniu czasem trudnym, innym razem przyjemnym.

\section{CZYM BYKO SANTIAGO DE COMPOSTELA?}

Santiago de Compostela bardziej niż miastem było „pamięcią apostolską" i zalążkiem tego miasta jest grób Apostoła. Miasto postrzega siebie przez pryzmat tysiącletniej tradycji, jako cel pielgrzymów z całego świata, którzy zmierzają do grobu Apostoła. Jego początki sięgają epoki przedrzymskiej, osady określanej jako Lovio, między rzekami Sar i Sarela, gdzie prawdopodobniej istniało miejsce kultu. W I wieku po Chrystusie pojawia się tu garnizon rzymski, który z biegiem czasu nabiera coraz większego znaczenia, stając się miejscem obronnym. W IV wieku zanikają stopniowo wpływy rzymskie, prowadząc do całkowitego opuszczenia osady wraz z upadkiem Imperium. Bardzo szybko dawne siedlisko rzymskie, opuszczone i znajdujące się w ruinie, stało się lasem: lasem Libredon, który miejscowi mieszkańcy uważali za święty ze względu na pewne pozostałości po świętościach. Na początku IX wieku Teodomir, biskup Iria, odkrywa w tym lesie grób apostoła Jakuba i to znalezisko zostaje potwierdzone przez króla Alfonsa II Czystego, który wybrawszy się na pielgrzymkę do tego miejsca wzniósł „kościół ku czci tak wielkiego Apostoła [i] zmienił miejsce rezydencji biskupa Iria na to właśnie miejsce, który nazywają Compostela" ${ }^{2}$.

Takie są początki miasta-celu pielgrzymek, które w pewnych momentach swej historii dorównywało, a nawet przekraczało pozostałe dwa miejsca pielgrzymkowe chrześcijaństwa: Jerozolimę i Rzym. Aż do tego czasu Compostela nie miała ani przeszłości, ani teraźniejszości. Było to miejsce zapomniane na krańcach Galicji, w którym odkryto na nowo grób Apostoła Jakuba w starej, opuszczonej nekropolii. Na niej wzniesiono wraz z upływem wieków sanktuarium o szczególnym pięknie i zdobieniach:

Compostela została założona: jako miasto duchowe od chwili, w której Apostoł wybrał ją na swój pochówek; historyczne i ziemskie, od chwili, gdy Alfon Czysty nakazał zbudowanie pierwszej bazyliki. Oba były od

${ }^{2}$ M. Suárez, J. Campelo (red.), Historia Compostelana, Santiago 1950, s. 21n. 
początku w myśli Boga. Ludzie, z roku na rok, wśród bólów i radości, realizowali w skale i duchowej łasce, te Boże schematy ${ }^{3}$.

W cieniu bazyliki rośnie małe miasto o nieco uśpionym charakterze, jak dobrze o tym wiemy z komentarzy wędrowców. A więc: co mogło przyciągnąć z taką siłą i łatwością pielgrzymów i podróżnych? Rozwój fenomenu jakubowego jest zadziwiający, jeśli przyglądamy mu się obiektywnie. Rodzi się z niczego i powstaje we wczesnym średniowieczu, z jednej strony stolica biskupia, które znajduje miejsce dla siebie w Galicji już pełnej wielu takich stolic, lecz pokonuje już istniejącą Iria, zastępując ją w 1095 roku; z drugiej strony powstaje „miasto, które jest w stanie wyjaśnić jedynie Duch i nie nauka", przechowując jeden z najcenniejszych skarbów Orbis Christianus i stając się celem dla pielgrzymów, spotkaniem różnych prądów duchowych, tendencji artystycznych, ekonomicznych i społecznych. W ten sposób

pielgrzymowanie do Santiago stało się jednym z tych mocnych elementów, które sprzyjały wzajemnemu zrozumieniu narodów europejskich tak różnych, jak te z kręgu kultury łacińskiej, Germanie, Celtowie, Anglosasi i Słowianie. Pielgrzymowanie przybliżało, sprawiało relację i jednoczyło między sobie tych ludzi, którzy wiek za wiekiem, przekonani przepowiadaniem świadków Chrystusa, przyjmowali Ewangelię4.

Tylko ten, kto ma w sobie zdolność do zdziwienia, będzie w stanie zrozumieć osnowę dachu tego miasta, które jest bardziej do tego, aby je kontemplować niż by o nim pisać i czytać.

Historia przekazuje nam obraz wzrastającego pielgrzymowania do Santiago de Compostela począwszy od jego zaraniu w IX wieku, przez całe średniowiecze i nawet potem już w nowożytności, przechodząc upadek począwszy od Rewolucji Francuskiej, końca Ancien Regiment i konkwiskat kościelnych. Pielgrzym, aby dotrzeć do Santiago, potrzebował noclegów, pożywienia, a czasami pomocy lekarskiej. Konkwiskaty pozbawiły i dokonały erozji bazy ekonomicznej, przyczyniając się do opuszczenia wielu klasztorów i szpitali, które obsługiwały pielgrzymów. Bez darmowego noclegu czy jedzenia, lub za symbo-

${ }^{3}$ G. Torrente Ballester, Compostela y su ángel, Madrid 1998, s. 55.

${ }_{4}^{4}$ Por. E. Moreno Baez, Los cimientos de Europa, Santiago de Compostela 1996, s. 7-8. Cytat za: Peregrinos por gracia. Carta pastoral del Arzobispo de Santiago en el Año Santo Compostelano 2004, Santiago de Compostela 2002, s. 102. 
liczną kwotę, pielgrzymowanie stało się mało możliwe dla szerokiego społeczeństwa.

\section{2. ŻYCIE JAKO PIELGRZYMOWANIE}

Pielgrzymowanie nie jest zwyczajnym odwiedzaniem jakiegokolwiek miejsca, aby podziwiać skarby natury, sztuki czy historii. Pielgrzymować oznacza raczej wyjść z samego siebie, aby spotkać się z Bogiem tam, gdzie On się objawil, gdzie łaska Boża ukazała się w całym blasku i przyniosła obfite owoce nawrócenia i świętości wśród wierzących. Chrześcijanie pielgrzymowali przede wszystkim do miejsc związanych z Męką, śmiercią i zmartwychwstaniem Pana, do Ziemi Świętej. Potem do Rzymu, miasta męczeństwa św. Piotra i św. Pawła, ale również do Composteli, która złączona z pamięcią o Jakubie, przyjmowała pielgrzymów z całego świata, pragnących wzmocnić swego ducha świadectwa wiary i miłości Apostoła 5 .

Człowiek, pielgrzymując, jest wierny sobie samemu, choć łaska wędrówki nie polega na szczęściu doczesnych, lecz na życiu w Chrystusie. Pielgrzym pokonuje ową drogę $\mathrm{z}$ tą pewnością, którą dają jedynie rzeczy Boże. Jako że pielgrzymka jest podróżą, której motywacja jest w pierwszym rzędzie religijna, warto zatrzymać się nad tym, co oznaczało dla człowieka starożytnego podróżowanie i relacje, jakie ono ustanawiało między podróżami, drogami a religią.

Podróżowanie $\mathrm{w}$ dawnych czasach niosło $\mathrm{z}$ sobą niebezpieczeństwo, ale przynosiło doświadczenie. To są dwa oblicza konstytutywne każdego pielgrzymowania. $Z$ jednej strony, ponieważ podróże oznaczały niebezpieczeństwo i to nie byle jakie, ale niebezpieczeństwo śmierci, nic dziwnego, że tworzyły się relacje między podróżami, pielgrzymkami, drogami i śmiercią, oraz z drugiej że krystalizowały się kulty bóstw opiekujących się podróżującymi czy pielgrzymami, a sama podróż nabierała znaczenia religijnego. Podróżowanie, pielgrzymowanie wnosiło doświadczenie, ale i vice versa, jedynie udając się $\mathrm{w}$ drogę, było się zdolnym do nabycia doświadczenia, wiedzy, a nawet prestiżu, a w miarę tego, że było to również niebezpieczne przyciągało odważnych. Połączenie ze sobą

${ }^{5}$ Benedykt XVI, Alocución en su llegada a Santiago de Compostela [Przemówienie powitalne w Santiago de Compostella], 6 listopada 2010. 
podróżowania, pielgrzymowania oraz wiedzy jest stałym zjawiskiem we wszystkich kulturach, choćby w najbardziej starożytnych.

Jeszcze $\mathrm{w}$ renesansie niektórzy utrzymują, jak Krzysztof Vilalon w swoim dziele Podróż z Turcji, że "owe nienasycone i nieokiełznane pragnienie wiedzy i poznania, które natura dała wszystkim ludziom... nie może lepiej się spełnić jak pielgrzymując i oglądając dalekie kraje" Dla renesansowego lekarza Paracelsusa „natura to 'kod', który należy czytać pielgrzymując i chodząc za nim". Choć mogło to być jedną z motywacji, które pchały w przeszłości do podróżowania - a jedną z form tego podróżowania było pielgrzymowanie - nie jest jednak jedynym kluczem, który pomaga nam zrozumieć fenomen pielgrzymowania do Santiago de Compostela. W sensie ścisłym pielgrzymowanie to podróż do jakiegoś sanktuarium mniej lub bardziej odległego, a więc zmiana miejsca ze względu na motywację religijną, co nie oznacza, że wraz z tą motywacją nie mogą pojawić się inne, jak choć już wcześniej wskazywane: chęć przygody, racje handlowe, polityczne, społeczne, psychologiczne czy wojskowe.

W tym kontekście powoli kształtuje się idea, że drogą, którą należy przebyć, jest przede wszystkim samo życie. Przechodzi się od drogi fizycznej do drogi jako symbolu, od kultu zewnętrznego do wewnętrznego. Albo mówiąc słowami Tomasza a Kempis w wieku XV: „Ten, kto potrafi podróżować wewnętrznie, nie szuka miejsc ani nie czeka na sposobny czas, aby oddać się pobożnym ćwiczeniom"7. To sam Chrystus przecież powiedział o sobie, że jest „drogą, prawdą i życiem” (J 14,6), obraz podjęty potem przez św. Pawła, gdy mówi o nim, że jest to „droga nowa i żywa zainaugurowana przez Niego [Chrystusa] dla nas ( $\mathrm{Hbr}$ 10,20). Ze swej strony św. Piotr utrzymuje, że chrześcijanin powinien żyć w świecie jak na obczyźnie, co jest równoznacznie ze stwierdzeniem, by żyć jak w podróży $(1 \mathrm{P} 1,1)$. Ale tym, który najbardziej rozwinął symbolikę drogi i życia jako podróży był chyba św. Augustyn z Hippony, który z naciskiem podkreślał, że nie przychodzi się na świat po to, aby pozostać na nim, ale jesteśmy tu przejazdem. Wszystkie te myśli krystalizują się we wczesnym średniowieczu w pojęciu homo viator. Gonzalo de Berceo, w pierwszej połowie XIII wieku, w ten sposób wyraził to we wprowadzeniu do Cudów naszej Pani:

${ }^{6}$ C. de Villalón, Viaje de Turquía, Buenos Aires - México 1946, s. 13

7 Tomasz a Kempis, O naśladowaniu Chrystusa, księga II, rozdz. 1. 
Wszyscy, którzy żyjemy jakoś stąpamy

nawet jeśli w więzieniu czy w łożu

wszyscy jesteśmy pielgrzymami idącymi drogą

Święty Piotr to mówi, przez niego wam to oznajmiamy

Ci, co tutaj żyjemy, będziemy mieszkać daleko,

wychwalajmy zatem naszą pielgrzymkę

gdy do raju wysyłamy duszę

To jest to założenie antropologiczne i religijno-teologiczne, na którym osadza się pielgrzymowanie do Santiago de Compostela. Chodzi o kondycję człowieka jako podróżnika, właściwą człowiekowi, to coś, co od początku tworzy historię ludzką, historię zarówno religijną, jak i świecką. W ramach perspektywy biblijnej droga jawi się jako coś ważnego, gdyż inspiruje w dużym stopniu samą historię biblijną od samych jej początków. W tym znaczeniu można powiedzieć, że droga nie tylko symbolizuje korzenie tego, co święte, lecz jest ekspresją możliwości historycznych chrześcijaństwa.

Droga pielgrzymkowa, opowiada Liber Sancti Jacobi, jest dobrą rzecza, ale wąską. Ponieważ wąska jest droga, która prowadzi człowieka do życia; natomiast szeroka i przestrzenna jest ta, która prowadzi do śmierci. Droga pielgrzymowania jest dla dobrych, pozbawionych wad, umartwiających ciała, dla wzrostu cnót, przebaczenia grzechów, pokuty pokutujących, drogą sprawiedliwych, miłości do świętych, wiary w zmartwychwstanie i nagrodą dla żyjących błogosławieństwami, oddaleniem od piekła i opieką niebios. Oddala od nasyconych źródła, sprawia, że znika dzikie obżarstwo, hamuje pożądliwość, trzyma w ryzach apetyty cielesne, które walczą przeciw mocy duszy, oczyszcza ducha, zaprasza człowieka do życia kontemplacyjnego, poniża wywyższających się, wywyższa pokornych, kocha ubogich...

\section{PIELGRZYMOWANIE, POWSZECHNY FENOMEN RELIGIJNY}

Pierwsze ogólne przybliżenie prowadzi nas do stwierdzenia, że jednym z największych fenomenów religijnych wszystkich czasów jest pielgrzymowanie; nie jest przypadkiem, że historia religii poświęca wiele uwagi praxis pielgrzymowania. Jest to jedno z określeń antropologicznych o największym zasięgu, wykraczającym poza poszczególne wyznania i może być traktowane jako pewna „parabola” egzystencji człowieka. 
Calderón de la Barca napisał: „choć peleryna zmienia dworzanina, ale nie przez to człowiek przestaje być pielgrzymem, ponieważ życie jest drogą. Gdy się rodzimy, zaczyna się ta droga, w ciągu życia postępuje, a nie osiąga swego kresu, gdy umieramy" 8 . W „Kazaniu świętego Papieża Kaliksta na uroczystość przeniesienia relikwii Apostoła Jakuba, którą się odprawia 30 grudnia" ujmuje pielgrzymowanie w perspektywie początku ludzkości, przypominając, że pielgrzymowania „nabiera imienia w Adamie; kontynuuje przez Abrahama, Jakuba i synów Izraela aż do Chrystusa, dopełnia się w Chrystusie i w apostołach"'. Adam jest pierwszym pielgrzymem, któremu zostaje obiecane po opuszczeniu raju (upadku, grzechu), powrót (obietnica). Życie pierwszego stworzenia jest niczym innym jak pielgrzymowaniem $\mathrm{w}$ oczekiwaniu na powrót do ostatecznego raju. Jego początek i jego cel to dwa jedyne odniesienia, aby wiedział, kim jest.

W najbardziej wewnętrznej części swego jestestwa, człowiek zawsze jest $\mathrm{w}$ drodze, ciągle $\mathrm{w}$ poszukiwaniu prawdy". Bycie pielgrzymem jako parabola ludzkiego losu to wiedza o tym, skąd przychodzi, jak zmierzamy i dokąd wędrujemy; to żyć w zgodzie z fundamentalnymi pytaniami ludzkiego bytu: skąd, którędy i dokąd. „Pielgrzymowanie jest czymś więcej niż sportem, więcej niż przygodą, więcej niż podróżą turystyczną, więcej niż szlakiem kulturowym prowadzącym przez cudowne budynki, milczących świadków świeckiej historii. Nie negując specyficznego znaczenia tych motywacji, pielgrzymka posiada jednak duszę ludzką i chrześcijańską, a gdy ta zostanie ograniczona traci swą wewnętrzną elokwencję, swoją moc budzenia ducha, swoją zdolność bratania ludzi i narodów. Bez duszy, Camino byłoby nic nie znaczącą rzeczywistością ${ }^{10}$.

\section{DUCHOWOŚĆ PIELGRZYMA}

Człowiek oczekuje, że pewnego dnia będzie mógł cieszyć się wiecznym szczęściem. Aż do tej chwili żyje w świadomości wygnańca,

${ }^{8}$ Cyt. za L.M. Herrán, Mariología poética espańola, Madrid 1988, s. 913.

${ }^{9}$ Liber Sancti Jacobi. Codex Calixtinus, tłum. A. Moralejo, C. Torres, J. Feo, Potevedra 1992, s. 207.

${ }^{10}$ R. Blazquez, Dimensión antropológico-religiosa de la peregrinación, "Compostelanum" 6 (1955), s. 8-9. 
stwierdzając trud drogi, ciężar samotności i wątpliwości. Duchowość wyjścia, exodusu, to tak, która jest właściwa człowiekowi walczącemu o wyzwolenie się z wszelkiej opresji, aby osiągnąć ziemię obiecaną. Przypowieść o synu marnotrawnym jest archetypem pielgrzymowania, w którym opisuje się oddalenie poprzedzające powrót i nawrócenie. Niesie to z sobą pewne postawy, jak skromności, dobrowolnego wyrzeczenia, pomimo drogi od tego, co znane, do tego, co nieznane, pozostając posłusznym wewnętrznemu głosowi, głosowi ducha, który nas zaprasza do czucia się obcymi we własnej ojczyźnie, wezwanych do bycia współobywatelami świętych.

Duch pielgrzymowania niesie z sobą wezwanie do pozostawienia własnej ziemi i bliskich, aby iść daleko, to znaczy, poza to, co bliskie i dostępne, co się zna lub posiada. Jest znakiem otwarcia na transcendencję. To pozostawienie, porzucenie jest czymś substancjalnym dla pielgrzyma. Nie ma wyjścia $z$ tego, co moje bez takiego wyzbycia się. Pojawia się $w$ opisie z Księgi Rodzaju zdanie: „Wyjdź z twej ziemi ojczystej, z domu Twego ojca, do kraju, który Ci wskażę i tam zbudujesz swój dom" (Rdz 12,1) - jest ono istotowym odniesieniem dla pielgrzyma. Pielgrzymi charakter człowieka wiary przemienia się w nadzieję jako dynamiczny element egzystencji. Tylko ten, kto czeka, może uważać się za pielgrzyma, kto podobnie jak Abraham wędruje przez świat, pytając czasem samego siebie gdzie jest Bóg, a choć osłabnie i pojawi się pokusa porzucenia poszukiwania, Bóg lituje się nad tym, kto w samotności i w milczeniu Go szuka. Pielgrzym staje się pośrednikiem dla innych osób i z perspektywy proroctw przyjmuje pełne objawienie się Boga w osobie Jego Syna Wcielonego.

Kto pielgrzymuje, uczy się mieć drzwi otwarte, ponieważ najpierw jemu zostały one otworzone. Ma świadomość, że egzystencja ludzka jest pełna paradoksów. Z jednej strony poruszamy się w kontekście, który nie jest ostateczny, w rzeczywistości historycznej, a z drugiej strony wychodząc od tej prowizoryczności jest $\mathrm{w}$ drodze do permanentnego obywatelstwa. „Nie mamy tutaj trwałego miasta, ale szukamy tego, które ma przyjść" (Hbr 13,14).

Wychwalanie, prośby i zaufanie to przejawy aktywności człowieka, który porusza się, przemieszcza się, człowieka w drodze (Ps 120-134), który przeżywa to napięcie między ziemią obcą a własnym miastem; których wychodzi z ojczyzny i wraca do niej, przynależy do społeczności aniołów i społeczności ludzi: „tutaj na ziemi pielgrzym z łaski, tam u góry dzięki łasce Bożej obywatel". W pewien sposób pojawia się tu myśl, że pielgrzymi powinni „żyć według Ducha i nie według ciała, według Boga 
i wedle ludzi". Określa to duchowość, która obok podstawowego wyboru opcji zawiera wielość różnych dróg osobistych, która nie odcina się od ludzkich uwarunkowań historycznych i zobowiązań do wolności i pomocy tam, gdzie chrześcijanin winien być zaczynem wolności i postępu, braterstwa i sprawiedliwości, z świadomością kościelną i ceniąc życie wspólnotowe. Pielgrzym odczuwa brak, opuszczenia własnego terytorium, ponieważ oczekuje i zmierza do miasta niebieskiego. Świadomość bycia pielgrzymem pomaga ze spokojem przekraczać przeszkody.

\section{PIELGRZYM DO SANTIAGO: PODRÓŻNIK ŚWIĘTOŚCl}

Pielgrzymowanie z daleka do Grobu Apostoła, z bagażem nocy i dni, radościami i troskami drogi, staje się obrazem życia chrześcijańskiego. Od samego początku Szlak św. Jakuba, ze względu na swe znaczenie i różnorodny wkład, stał się ważnym zjawiskiem, który ukształtował w dużej części byt Europy; a stało się to możliwego dlatego, że pielgrzym jakubowy nieprzerwanie pielęgnował w sobie powołanie wędrowca, które czyniło z niego "podróżnika świętości” i przekaziciela wiedzy. Jego celem był grób Apostoła, który według tradycji ewangelizował Hiszpanię. Był to pielgrzym wyjątkowy, różniący się od zwykłego wędrowca. Jego metą było spotkanie z Chrystusem, do którego dochodziło dzięki apostołowi Jakubowi. W tym sensie można powiedzieć, że nigdy nie brakowało albo prawie nigdy, intencji o charakterze duchowym, gdyż chodziło przecież o podróż związaną z nawróceniem i przemianą, podróż świętą prowadzącą przez cały ówczesny świat chrześcijański. Inspiracją popychającą do drogi była pobożność i kult św. Jakuba, poszukiwanie osobistej z nim relacji. Była to postawa pielgrzyma przenikniętego wiarą i głębokiego czciciela Apostoła, co nie wykluczało innych motywacji, takich jak: pragnienie własnego uświęcenia, konieczność większej praktyki modlitwy, wdzięczności za otrzymane łaski, zobowiązanie wypełnienia jakiejś obietnicy, nie zapominając o chęci otrzymania odpustów ${ }^{11}$ czy uproszenia cudu. Bez wątpienia istotnym elementem takiego pielgrzymowania był duch pokuty. Szło się do Compostela "dla pokuty”, zarówno gdy była ona decyzją osobistą, albo na mocy delegacji albo zlecenia przez kogoś, kto nie mógł jej sam odbyć. Pokonywanie trasy pieszo, całej lub

${ }^{11}$ W 1294 roku papież Celestyn V po raz pierwszy udzielił odpustu zupełnego za podjęcie i odbycie pielgrzymki. 
jej części, zawsze było jednym ze środków czynienia pokuty. Oznacza to, że Camino de Santiago i pielgrzymowanie jakubowe od samych swoich początków było historią wiary, świadectwem życia chrześcijańskiego, braterskiej miłości: historią, która ukształtowała chrześcijańską Europę.

Niemniej jednak trzeba pamiętać, że osoba odbywająca podróż do Santiago, podróż z istoty religijną, jest jednocześnie osobą ciekawą i uważną, która potrafi podziwiać i pochłaniać niejako to, co spotyka, począwszy od pieśni, opowiadania i legendy aż po wyjątkowe techniki arabskie obserwowane w królestwach hiszpańskich. Oznacza to, że wraz z pielgrzymami jakubowymi podróżowały idee, instytucje, legendy, jednym słowem, istotne elementy kulturowe. Pielgrzymi przynosili do królestw hiszpańskich nowe formy wyrazu artystycznego, symbole, wierzenia i formy życia, które pozostali tam, którędy przechodzili; a nawet na końcu drogi, w postawie pokutnej, brali na siebie wapienne skały, aby wnieść swój wkład w budowę bazyliki kompostelańskiej.

Codex Calixtinus, pierwszy przewodnik dla podróżnych i pielgrzymów na zachodzie, opisuje nam pielgrzyma jakubowego jako najbardziej charakterystycznego wśród pielgrzymów chrześcijańskich. Nie bez znaczenia później Dante nazwie pielgrzymem (peregrinus) tego, kto zmierza do Domu Pana Jakuba, 'palmero" tego, kto udaje się do Jerozolimy i 'romero' tego, kto zmierza do Rzymu. Renesans wiedział dobrze, że fenomen jakubowy ściśle się złączyć z fenomenem pielgrzymowania w ogóle.

Szlak św. Jakuba był więc od początku drogą wiary i drogą kultury, to znaczy, najważniejszym wydarzeniem w konfiguracji średniowiecznej Europy jako zachodniego chrześcijaństwa. To przekonanie przedstawia Eneas Silvio Piccolomini, papież-humanista Pius II (1405-1464), wskazując w swoim dziele kartograficznym na pewną religijno-kulturową jedność Europy w przeciwieństwie do tego, co nazywał barbarzyństwem azjatyckim. Piccolomini jasno pokazał $w$ swoich rozważaniach istnienia powiązania między Europą a cywilizacją, między chrześcijaństwem a cywilizacją, która jest właśnie jednym z wielkich wkładów Szlaku św. Jakuba i pielgrzymek jakubowych.

Po tej samej linii jak jego poprzednik Pius II, już w naszych czasach bł. Jan Paweł II wprost przypominał o wkładzie pielgrzymowania jakubowego w budowanie jedności i spójności Europy: „Cała Europa spotkała samą siebie wokół 'pamięci' Jakuba, w tych samych wiekach, w których budowała siebie jako kontynent jednorodny i duchowo zjed- 
noczony. Z tego powodu Goethe wskazywał, że świadomość europejska narodziła się pielgrzymując"12.

\section{ZASŁUGI I WKŁAD DLA EUROPY}

Pielgrzymowanie jakubowe uwypukliło pierwszeństwo dóbr duchowych; utrzymało napięcie skierowane na dobra Boże; zainspirowało i wspierało inicjatywy oraz instytucje promujące wartości ludzkie; i nadal pozostaje światłem dla tych wszystkich, którzy troszczą się o autentyczny humanizm i przyszłość Europy, aby potrafili odkryć, docenić i bronić bogatego dziedzictwa kulturowego i religijnego.

\subsection{PIERWSZY WKŁAD: ANTROPOLOGIA CHRZEŚCIJAŃSKA}

Trudno wyróżnić wszystkie antropologiczne wymiary, które kryją się w przesłaniu pielgrzymim: dobroć stworzenia i stworzeń; zagrożenie i konsekwencje grzechu; możliwości człowieka, aby zostać uleczonym, nawróconym, uzyskać przebaczenie; obecność łaski w niedoskonałym stworzeniu, które znajduje się w drodze do swej pełni. Jedynie duchowa siła prawdy Chrystusa może pokonać mentalną i moralną słabość, której podlegamy oraz pomóc nam odzyskać zaufanie: „Bez zaufania do egzystencji, na której się opieramy, dając jej specyficzny kredyt i zdolność do kontynuacji w przyszłości, nie jest możliwe owe działanie stwórcze, które przemienia naturę dla lepszej służby człowiekowi, która wzbudza i odkupia człowieka, która walczy, aby pokonać śmierć. Brak zaufania prowadzi nas do trywialności.

\subsection{DRUGI WKŁAD: JEDNOŚĆ}

Pielgrzymowanie jakubowe odkrywa, że chrześcijaństwo ze względu na swoją otwartość na to, co powszechne, dokonało konfiguracji Europy otwartej i zdolnej z tego powodu do włączania nowych elementów. Ale tego nie można dokonać bez szacunku dla kulturowej tożsamości Europy. Trzeba o tym powiedzieć, wiedząc, skąd przychodzimy i aby kroczyć ku

12 Por. Peregrinos por gracia. Carta pastoral del Arzobispo de Santiago de Compostela en el Año Santo Compostelano 2004, s. 99. 
przyszłości z nadzieją. „Europa rozumie siebie przede wszystkim z punktu widzenia kulturalnego i nie została stworzona przez nic innego jak tradycję chrześcijańską. Kultura europejska nie przetrwa, gdy całkowicie zniknie wiara chrześcijańska. Jeśliby chrześcijaństwo zniknęło, cała nasza kultura zniknęłaby wraz z nim". Tradycja jakubowa miała decydujące znaczenie dla jedności Europy. Porzucenie tej tradycji jest pozbywaniem się inspiracji i pomocy dla jednego z największych wyzwań teraźniejszości: jedności. Autorytet Boga, który wiąże nasze sumienia i przyciąganie przez to, co święte, a co nas prowadzi do działania, są niezbędnymi założeniami.

\subsection{TRZECI WKŁAD: PROJEKT ETYCZNO-MORALNY}

Potrzeba ożywienia świadomości europejskiej żywej i twórczej, której pierwszą treścią, wcześniejszą od wszystkich traktatów i uregulowań polityczno-ekonomicznych, będzie osiągnięcie solidarności moralnej, która powinna stać się prawdziwym „szpikiem kostnym” Europy, jak mówi Salvador de Madariaga. Świadomość Europy wyróżnia się i wyraża w recepcji arystotelizmu w Paryżu, prawa rzymskiego w Bolonii, nauk arabskich w Toledo, handlu i żeglugi w Wenecji czy Brugii. Korzenie poczucia europejskości trzeba poszukiwać we wspólnej kulturze wszystkich ludów europejskich. A siłą dominującą $\mathrm{w}$ tworzeniu wspólnej kultury różnych ludów jest religia. Fundamentem kultury jest religia. Najbardziej intymne przekonania człowieka o jego przeznaczeniu określają jego postawę wobec problemów, które stawia mu życie, a z których rozwiązań rodzi się kultura. Religia jest uniwersalna i transcendentna; kultura rozwija się na planie tego, co jednostkowe i czasowe.

Oczywiście nie chodzi o to, aby stworzyć Europę paralelną do tej już istniejącej, lecz do pokazania tej Europie, że jej dusza i tożsamość są głęboko zakorzenione $\mathrm{w}$ chrześcijaństwie, aby w ten sposób móc podarować Europie klucz do interpretacji jej własnego powołania w świecie. Jedność Europy będzie trwała i owocna, jeśli oprze się na wartościach ludzkich i chrześcijańskich, które tworzą jej wspólną duszę, takie jak godność osoby ludzkiej, głębokie poczucie sprawiedliwości i wolności, pracowitość, duch inicjatywy, miłość do rodziny, szacunek wobec życia, tolerancja i pragnienie współpracy i pokoju.

Europa nauki i technologii, Europa cywilizacji i kultury, musi być jednocześnie Europą otwartą na transcendencję i braterstwo z innymi kon- 
tynentami, na Boga żywego i prawdziwego od człowieka prawdziwego i żywego. To chciałby wnieść Kościół w Europę: czuwać nad Bogiem i czuwać nad człowiekiem, z perspektywy rozumienia obu, która została nam podarowana w Jezusie Chrystusie ${ }^{13}$.

Wspomniany system wartości - wiara, solidarność, miłość, ofiara, postawa pokutna i transcendencja - powiązany z pielgrzymowaniem jakubowym sprawił, że dojrzała i wzmocniła się chrześcijańska koncepcja relacji między ludźmi z różnych krajów i o odmiennych zwyczajach, złączonych tą samą wiarę i uczestniczących w tej samej cywilizacji, która nadal pozostaje dla wielu punktem odniesienia. Dlatego Europa nie może postrzegać siebie jedynie jako struktura ekonomiczna bazująca na wspólnocie monetarnej.

Chciałbym zaprosić Hiszpanię i Europę do budowania teraźniejszości i projektowania przyszłości w oparciu o autentyczną prawdę o człowieku, o wolność, która szanuje prawdę i nigdy jej nie rani, oraz w oparciu o sprawiedliwość dla wszystkich, począwszy od najbardziej ubogich i bezbronnych. Hiszpanię i Europę nie tylko przejętych troską o materialne potrzeby ludzi, lecz także moralne i społeczne, duchowe i religijne, ponieważ wszystkie one są naturalnymi wymaganiami człowieka i jedynie w ten sposób pracuje się skutecznie, integralnie oraz twórczo dla jego dobra ${ }^{14}$.

Jedność europejska powinna budować się na systemie wartości osobistych i wspólnotowych, w których życie jest rozumiane jako dar i zadanie dla człowieka, w którym bliźnim jest ten, za którego każdy czyni się odpowiedzialnym i gdzie życie każdego zostaje oddane w służbę innym.

Na tym horyzoncie pielgrzymowanie jakubowe przestaje posiadać wartość wyłącznie kulturową i historyczną, ale nabiera wartości konstytutywnej i tworzącej wspólną cywilizację europejską. Pośród indyferentyzmu religijnego, niepewności moralnej, braku rozeznania i utraty wizji transcendentnej, winniśmy w takich chwilach wyjść z naszej starej drogi i zacząć w nowy sposób wyjaśniać, czy udzielać trafnych odpowiedzi (por. M. Scout Pecto, Un camino sin huellas). Co grozi życiu osobistemu? Groźba anonimowości, trywializacji zła, technicznej i medialnej redukcji języka, powtarzania do znudzenia tych samych treści, ekspresywnego

${ }^{13}$ Benedykt XVI, Homilia na Placu del Obradoiro, 6 listopada 2010.

${ }^{14}$ Benedykt XVI, Przemówienie w katedrze w Santiago, 6 listopada 2010. 
ujednolicania, zapomnienia o światach dalekich od naszej bezpośredniej percepcji i języka, milczenie wokół sfery świętości niedostępnej dla metod ilościowych. Niech ludzie dobrzy, twórcy, poeci, święci stworzą nam na nowo te prawdziwe i potrzebne słowa, którymi wyrażamy świat, nas samych i zwracamy się nimi ku Bogu"15. Jak wczoraj, tak i dziś

Jakub jest namiotem spotkania, celem pielgrzymowania, znakiem Kościoła pielgrzymującego i misyjnego, pokutującego i wędrującego, modlącego się i ewangelizującego, głoszącego Krzyż Pana aż do nas powróci. Compostela, miejsce przestrzenne i o drzwiach otwartych, pragnie stać się jaśniejącym blaskiem chrześcijańskiego życia, rezerwuarem energii apostolskiej dla nowych dróg ewangelizacji, w służbie impulsów wiary, zawsze młodej (Jan Paweł II) ${ }^{16}$.

Tłum. z jęz. hiszp. - ks. Piotr Roszak

Streszczenie. Celebrując Rok Wiary, który zaprasza nas do wyznania, celebrowania i dania świadectwa naszej wierze, musimy wiernie odczytać sytuację bieżącą w świetle tajemniczej lampy wiary. Począwszy od IX w., poprzez średniowiecze, po współczesność, historia notuje niezwykły rozwój pielgrzymek do Santiago de Compostela. Znaczące elementy kulturowe, takie jak idee, instytucje, legendy, zostały przyniesione przez jakubowych pielgrzymów. Przynosili oni do hiszpańskich królestw nowe formy artystycznej ekspresji, symbole, wierzenia i style bycia, łączące miejsca, przez które przechodzili. Co więcej, u końca drogi o charakterze pokutnym, nieśli wapień, który później posłużył przy budowie bazyliki w Santiago. Droga do Santiago była od początku wyprawą wiary, wyprawą kultury, najważniejszym wydarzeniem w kształtowaniu średniowiecznej Europy jako zachodniego chrześcijaństwa.

Słowa kluczowe: Santiago de Compostela; pielgrzymka; wiara; szlak św. Jakuba.

Abstract. Transcendent sense of the Way to Santiago. When we are celebrating the Year of Faith, which invites us to confess, celebrate and witness our faith, we must make a faithful reading of the current situation with the light of the mysterious lamp of faith. History records the unusual breadth of the pilgrimage to Santiago de Compostela from its beginnings in the ninth century, during the Middle Ages until today. Important cultural elements, such as ideas, institutions, legends,

${ }^{15}$ O. Gonzalez De Carderal, Unas pocas palabras verdaderas, ABC 3 kwietnia 2008.

${ }^{16}$ Jan Paweł II, Przemówienie na Plaza del Obradoiro, 19 sierpnia 1989, podczas realizacji rytu pielgrzymiego. 
were brought by the Jacobean pilgrims. Pilgrims brought to the Spanish kingdoms new forms of artistic expressions, symbols, beliefs and ways of life, which joined the places they crossed, even at the end of the way in penitential attitude, they loaded limestone to contribute in building the basilica of Santiago. The Way to Santiago has been a journey of faith and a journey of culture from the beginning, the most important event in shaping the medieval Europe as Western Christianity.

Keywords: Santiago de Compostela; pilgrimage; faith; way to Santiago. 